\title{
Physical Quality Assessment of Aceh Cattle Meat and Their Relationship with Meat Types and Hair Color Differences
}

\author{
Al Azhar ${ }^{1,9 *}$, Muslim Akmal ${ }^{2,9}$, Muhammad Hambal $^{3}$, Mustafa Sabri ${ }^{4}$, Teuku S. Rosa ${ }^{5}$, Rahmaddiansyah \\ Rahmaddiansyah $^{6}$, Bambang Purwantara ${ }^{7,9}$, and Dasrul Dasrul ${ }^{8}$ \\ ${ }^{1}$ Laboratory of Biochemistry, Faculty of Veterinary Medicine of Universitas Syiah Kuala, Darussalam Banda Aceh, 23111 Indonesia \\ ${ }^{2}$ Laboratory of Histology, Faculty of Veterinary Medicine of Universitas Syiah Kuala, Darussalam Banda Aceh, 23111 Indonesia \\ ${ }^{3}$ Laboratory of Parasitology, Faculty of Veterinary Medicine of Universitas Syiah Kuala, Darussalam Banda Aceh, 23111 Indonesia \\ ${ }^{4}$ Laboratory of Anatomy, Faculty of Veterinary Medicine of Universitas Syiah Kuala, Darussalam Banda Aceh, 23111 Indonesia \\ ${ }^{5}$ Veterinary Public Health Master Program, Faculty of Veterinary Medicine of Universitas Syiah Kuala, Darussalam Banda Aceh, \\ 23111 Indonesia \\ ${ }^{6}$ Agricultural Faculty of Universitas Syiah Kuala, Darussalam Banda Aceh, 23111 Indonesia \\ ${ }^{7}$ Department of Reproduction, Faculty of Veterinary Medicine of Bogor Agricultural University, Campus Dramaga Bogor, Indonesia \\ ${ }^{8}$ Laboratory of Reproduction, Faculty of Veterinary Medicine of Universitas Syiah Kuala, Darussalam Banda Aceh, 23111 Indonesia \\ ${ }^{9}$ Center for Collaborative Research Animal Biotechnology and Coral Reef Fisheries (CCR ANBIOCORE), USAID-SHERA
}

\begin{abstract}
This study aimed to investigate the physical quality of silverside and sirloin meats of aceh cattle, Indonesian beef cattle native to Aceh Province. Meat samples, 250-300 gram each, were collected in triplicate from cull female Aceh cattle have different hair colors slaughtered at the Slaughter House of Banda Aceh. Meat and fat colors, marbling, texture, $\mathrm{pH}$, drip loss and cooking loss were determined using the SNI method and analyzed using Chi-Square and Pearson's correlation tests. The results showed that meat color of cull female Aceh cattle have different hair colors ranged from bright to dark red and were insignificant $(p>0.05)$ between hair colors and meat types. The texture of sirloin meat ranged from smooth to medium and that of silverside was medium. Silverside meat fat color (6.06 \pm 1.61$)$, marbling (3.50 \pm 1.42$), \mathrm{pH}(6.68$ $\pm 0.40)$, drip loss $(9.06 \pm 3.14 \%)$ and cooking loss $(30.13 \pm 10.84 \%)$ were indifferent from those of sirloin meat (fat color $6.06 \pm 1.63$, marbling $3.67 \pm 1.81$, pH $6.72 \pm 0.49$, drip loss $9.12 \pm 5.84 \%$, cooking loss $32.06 \pm 7.30 \%$ ). In conclusion, the physical quality of sirloin and silverside meats of cull female Aceh cattle were categorized into grade I-III and not influenced by hair colors.
\end{abstract}

Keywords: Aceh cattle, meat, marbling.

\section{Introduction}

Different from those occurred in advanced countries where beef production has been done in improved techniques to offer more males for slaughter and better replacement heifers [1], local beef cattle in Indonesia is mainly $(90 \%)$ produced by smallholder, traditional farming systems involving around 6.5 million farmers living in the rural areas [2]. This might be responsible for the less $(45 \%)$ contribution of beef cattle production to national meats demand [3]. Limited supply [3, 4] and less male and more cull, old female for slaughter [5] also make people pay high prices.

A similar situation occurred in the production of aceh cattle. The total population of aceh cattle in 2011 is predicted less than 550,000 heads, $20,57 \%$ less than those reported in 2010, 688,118 heads [6]. Aceh cattle slaughtered at the Slaughter House of Banda Aceh in 2018 are only 361 heads ( 80 male and 281 cull female), represents $14.07 \%$ out of total cattle slaughtered at the facility in the year [Slaughter House of Banda Aceh, 2019, unpublished data]. These facts contrast to the high consumption - more than 10 tons per day - of meats during Islamic big days [7]. Total cattle slaughtered in Eid Mubarak 2014 in Aceh, for example, reach 10,880 heads [8].

Despite its less slaughtering and reduced breeding numbers compared to the crossbreed counterparts [Slaughter House of Banda Aceh, 2019, unpublished data], Aceh cattle has special value for the Acehnese because this cattle has been stated as one of germ-plasma of Indonesian cattle [9], and the majority of Acehnese believe that the meats of aceh cattle are tastier than those of other Indonesian cattle or even those of exotic cattle. Scientific evidence must be provided due to the following reasons. Aceh cattle was formed from blood intermixture between Indonesia local cattle (Bos sondaicus) and zebu (Bos indicus) $[10,11]$. Similar to other Indonesian local

\footnotetext{
* Corresponding author: alazhar@unsyiah.ac.id
} 
cattle, Aceh cattle have better resistance to parasitic diseases and more adaptive to tropical climate compared to exotic cattle), characters represent to Zebu genotype[1]. Zebu genotype, however, causes an undesired effect on meat quality in cattle, in particular, tenderness [1214].Our previous study showed that the physical quality of silverside meats of female aceh cattle have brick-red hair color is low as reflected by bright red meat color, low intramuscular fat (marbling 1), yellowish fat color, and though (tenderness $3.70 \pm 0.20$ ) [15]. Naturally, Aceh cattle might have various hair colors namely light brown, red-brown (brick red), dark brown, black and white, and gray [16]. We believe that hair color and meat-type influence meat quality of Aceh cattle, but no scientific information describe these effects in both male and female Aceh cattle. The objective of this study was to evaluate the physical quality of sirloin and silverside meats of cull female aceh cattle that have different hair colors and slaughtered at the Slaughter House of Banda Aceh.

\section{Materials and Methods}

\subsection{Ethical approval}

All methods used in the study have been approved by the Ethical Committee of Experimental Animals of Veterinary Faculty of Universitas Syiah Kuala No. 28/KEPH/11/2018.

\subsection{Meat samples collection}

Sirloin and silverside meats of Aceh cattle have targeted hair colors (yellowish red, grayish black, brick red, black, white, and light yellow) were purchased in quadruplicate from the traders used commercial slaughtering service provided by the Slaughter House of Banda Aceh. Meat samples, 250-300 g each, were brought in ice condition to the Laboratory of Veterinary Public Health of Veterinary Faculty of Universitas Syiah Kuala and subjected for physical quality examination.

\subsection{Analysis of meat physical quality}

Four out of seven physical quality parameters investigated in this study (meat color, texture, fat color, and marbling) were determined using protocols listed in the Indonesian National Standard (SNI) 3932:2008. In brief, meat and fat color (score 1-9), were visually determined by individually comparing the color of meat and subcutaneous fat observed with color standards listed in the reference sheets. Whilst marbling (score 1-12) was also visually determined by comparing the intramuscular fat density of the transversally cut meat to marbling standard sheet, visual determination of meat texture (soft, medium, or rough) was done by comparing texture observed with the standards listed in the reference sheet. Classification of meat grade (I, II and III) was performed by combining interpretation of meat and fat color, marbling, and texture scores recorded [17].

Meat $\mathrm{pH}$ was measured by rinsing of a probe of calibrated $\mathrm{pH}$-meter () in 25 gram grinded meat diluted in the same volume of distilled water [18]. Drip loss was determined according to Lukman et al.[19]. Briefly, $5 \mathrm{~g}$ of meat samples were centrally hung using a string in a plastic bag and stored for 48 hours in a refrigerator (4-7 $7^{\circ}$ C). The meat was then taken out, dried by using a tissue paper and weighted. Drip loss was represented by the weight loss during the storage in percent [19]. For cooking loss measurement, meat samples ( 70 gram) were put in a vacuum plastic bag and heated for 40 minutes in hot water $\left(75^{\circ} \mathrm{C}\right)$. After cooling the bag for 40 minutes using tap water, samples were taken out, dried using a tissue paper, and weighed. The percentage of weight loss during cooking represented the cooking loss [19].

\subsection{Data analysis}

Data obtained were analyzed by Chi-square and Pearson analysis using SPSS version 20 for Windows.

\section{Results and Discussion}

\subsection{Results}

Meat physical qualities evaluated in this study were meat and fat color, texture, marbling, $\mathrm{pH}$, cooking loss and drip loss. Results of the physical quality of the sirloin and silverside meats analyzed are presented in Table 1 and their $\mathrm{pH}$ and water holding capacity are listed in Table 2.

Data in Table 1 showed that sirloin and silverside meats of Aceh cattle having straight yellow, yellowish red, grayish black, brick red, black and white hair colors had comparable physical quality. The color of silverside and sirloin meats of cull female aceh cattle range from bright red to dark red (score $4-8$ ), average score meat color of silverside and sirloin meats were $7.00 \pm 1.37$ and $7.00 \pm 1.37$, respectively. Fat color of silverside and sirloin meats varied from yellowish-white to yellow, and statistically insignificant $(6.06 \pm 1.61$ vs. $6.06 \pm 1.63)$. Marbling scores ranged from 1-8 in sirloin meat and 3-8 in silverside meat, but they are statistically insignificant.

The physical quality of sirloin meat was higher than that of silverside meat in Aceh cattle having straight yellow, yellowish red, grayish black, and brick red hair colors (Table 1). A lower sirloin meat quality than silverside was observed in Aceh cattle having black or white hair color. Sirloin meats of Aceh cattle tend to have less intramuscular fat than its silverside counterpart. Statistical analysis indicated that the marbling score of sirloin meat significantly higher than that of silverside meat in aceh cattle has white hair color. This is a contrast to that found in aceh cattle have black hair color where silverside meat had significantly higher marbling than sirloin meat.

The $\mathrm{pH}$, drip loss and cooking loss of silverside and sirloin meats of Aceh cattle showed some variations but no difference was observed between the meats. Silverside meat $\mathrm{pH}(6.68 \pm 0.40)$, drip loss $(9.06 \pm 3.14 \%)$ and cooking loss $(30.13 \pm 10.84 \%)$ were statistically indifferent from those of sirloin meat $(\mathrm{pH} 6.72 \pm 0.49$, drip loss $9.12 \pm 5.84 \%$, cooking loss $32.06 \pm 7.30 \%$ ). As presented in Table 2, insignificant $\mathrm{pH}$, drop loss and 
cooking loss were also observed between cattle have different hair colors. There was a tendency of higher values of drip loss or cooking loss in silverside meat than those in sirloin meat of aceh cattle have certain hair colors

Table 1. Physical quality parameters of silverside and sirloin meats of aceh cattle have different hair colors

\begin{tabular}{|c|c|c|c|c|c|c|c|}
\hline \multirow[b]{2}{*}{ Cattle Hair color } & \multirow[t]{2}{*}{ Meat type } & \multirow[b]{2}{*}{$\mathbf{N}$} & \multicolumn{4}{|c|}{ Physical quality } & \multirow[b]{2}{*}{ Grade } \\
\hline & & & Meat color & Fat color & Marbling & Texture & \\
\hline \multirow{2}{*}{ Straight yellow } & Silverside & 4 & $7.50 \pm 1.29$ & $5.50 \pm 1.73$ & $2.75 \pm 0.96$ & Smooth to medium & I-II to II-III \\
\hline & Sirloin & 4 & $6.50 \pm 2.08$ & $4.50 \pm 1.29$ & $4.00 \pm 1.15$ & Medium & II - III \\
\hline \multirow{2}{*}{ Yellowish Red } & Silverside & 3 & $7.67 \pm 1.15$ & $5.67 \pm 2.31$ & $3.67 \pm 1.53$ & medium & I-II to II-III \\
\hline & Sirloin & 3 & $7.33 \pm 0.58$ & $6.00 \pm 2.65$ & $2.67 \pm 1.15$ & Smooth to medium & I-II to II-III \\
\hline \multirow{2}{*}{ Brick red } & Silverside & 2 & $7.50 \pm 2.12$ & $5.50 \pm 3.54$ & $2.50 \pm 0.71$ & medium & I-II to II-III \\
\hline & Sirloin & 2 & $7.50 \pm 0.71$ & $5.50 \pm 2.12$ & $2.00 \pm 0.00$ & Smooth to medium & I-II to II-III \\
\hline \multirow{2}{*}{ Greyish black } & Silverside & 5 & $7.20 \pm 0.84$ & $6.20 \pm 0.45$ & $4.00 \pm 1.87$ & Medium & Ii to II-III \\
\hline & Sirloin & 5 & $6.20 \pm 1,48$ & $6.40 \pm 0.55$ & $3.40 \pm 2.07$ & Medium & I to II-III \\
\hline \multirow{2}{*}{ White } & Silverside & 2 & $7.50 \pm 0.71$ & $7.00 \pm 0.00$ & $3.00 \pm 1,41$ & Medium & II - III \\
\hline & Sirloin & 2 & $8.00 \pm 0.00$ & $7.50 \pm 0.71$ & $6.50 \pm 2.12$ & Medium & II-III \\
\hline \multirow{2}{*}{ Black } & Silverside & 2 & $8.00 \pm 1.41$ & $7.00 \pm 0.00$ & $5.00 \pm 0.00$ & Medium & II - III \\
\hline & Sirloin & 2 & $8.00 \pm 0.00$ & $7.50 \pm 0.71$ & $4.00 \pm 1.41$ & Medium & II - III \\
\hline
\end{tabular}

\subsection{Discussion}

The quality of meats of local beef cattle usually consumed and preferred by Indonesian people living in certain parts of the Indonesian archipelago is still limited. Meat quality can easily be evaluated based on physical quality such as meat color, marbling and texture. This practice generally does by people in western countries when buying meats When carrying out a study to investigate potential genetic markers for meat quality of Aceh cattle have different hair colors we found that the majority of aceh cattle slaughtered at the Slaughter House of Banda Aceh were cull female aceh cattle. Evaluation of the quality of these meats was done based on several parameters of meat physical quality namely meat color, fat color, marbling, texture, $\mathrm{pH}$, drip loss and cooking loss. The results obtained showed that silverside and sirloin meats of cull female Aceh cattle ranged from grade I and III as indicated by bright red to dark red meat color, yellowish white to yellow fat color, low to medium marbling and medium texture.

The $\mathrm{pH}$ score is one of the criteria used in determining meat quality. The respective $\mathrm{pH}$ of silverside and sirloin meats analyzed, $6.68 \pm 0.40$ and $6.72 \pm 0.49$, are in the normal postmortem $\mathrm{pH}$ changes of beef. Meats of healthy animals and raised under good management undergoes gradual reduction of $\mathrm{pH}$ after slaughtering from $7.0-7.2$ to $5.6-5.7$ in $6-8$ hours postmortem before reaches ultimate $\mathrm{Ph}$ of $5.5-5.6$ [20]. The $\mathrm{pH}$ is formed from the accumulation of lactic acid resulted during anaerobic glycolysis until all glycogen storages diminish or until $\mathrm{pH}$ created is low enough to inactivate glycolytic enzymes [21]. A fast decline of $\mathrm{pH}$ postmortem has to be avoided due to its negative effects on color and tenderness.

Meat $\mathrm{pH}$ is closely related to water holding capacity, another important parameter of meat quality because water roughly constitutes $75 \%$ of meat weight [20]. Water content in the meats of Bos indicus cattle, $77.50 \pm 0.40 \%$ [22], is higher than that in the meat of Bos taurus cattle, $72.4-74.8 \%$ [23]. Silverside meat of Aceh cattle, which is formed from the blood intermixture of Bos indicus and Bos sondaicus [10, 11], contain water $72.87 \pm 0.50 \%$ [15], almost similar to that contained in the meat of bali cattle (Bos sondaicus), 72.84 $\pm 0.79 \%$ [24]. Due to its high water content, fresh rigor mortis meat normally give offs fluid, or drip, from cut surfaces [20]. Drip loss is important for the meat industry because of its significant economic inferences. Beef with high drip loss generally has an unattractive appearance and texture, and reduced nutritional value, and therefore low consumers' acceptance, which results in reduced salable [20, 25]. 
Table 2. The $\mathrm{pH}$ and water holding capacity of sirloin and silverside meats of aceh cattle have different hair colors

\begin{tabular}{|c|c|c|c|c|}
\hline Cattle hair color & Meat type & pH & Drip loss (\%) & Cooking loss (\%) \\
\hline \multirow{2}{*}{ Straight yellow } & Silverside & $6.65 \pm 0.21$ & $7.65 \pm 3.87$ & $29.19 \pm 5.63$ \\
\hline & Sirloin & $6.77 \pm 0.31$ & $8.00 \pm 5.66$ & $32.92 \pm 2.52$ \\
\hline \multirow{2}{*}{ Yellowish red } & Silverside & $6.78 \pm 0.46$ & $10.00 \pm 2.60$ & $22.97 \pm 11.13$ \\
\hline & Sirloin & $6.55 \pm 0.57$ & $8.90 \pm 4.59$ & $28.67 \pm 8.32$ \\
\hline \multirow{2}{*}{ Brick red } & Silverside & $6.34 \pm 0.65$ & $10.45 \pm 3.18$ & $29.60 \pm 8.06$ \\
\hline & Sirloin & $6.49 \pm 1.00$ & $8.20 \pm 1.70$ & $35.50 \pm 10.04$ \\
\hline \multirow{2}{*}{ Grayish black } & Silverside & $6.64 \pm 0.56$ & $7.48 \pm 2.19$ & $29.20 \pm 16.44$ \\
\hline & Sirloin & $6.77 \pm 0.64$ & $10.58 \pm 9.22$ & $29.30 \pm 8.94$ \\
\hline \multirow{2}{*}{ White } & Silverside & $6.75 \pm 0.19$ & $13.20 \pm 1.41$ & $35.71 \pm 6.07$ \\
\hline & Sirloin & $6.93 \pm 0.35$ & $12.90 \pm 4.10$ & $39.55 \pm 10.68$ \\
\hline \multirow{2}{*}{ Black } & Silverside & $6.99 \pm 0.06$ & $8.90 \pm 4.10$ & $39.99 \pm 7.38$ \\
\hline & Sirloin & $6.80 \pm 0.21$ & $5.20 \pm 2.26$ & $31.41 \pm 0.13$ \\
\hline
\end{tabular}

This study found that drip loss of silverside and sirloin meats measured $(9.06 \pm 3.14 \%$ and $9.12 \pm 5.84 \%$, respectively) were not significantly different. Insignificant drip loss differences were also observed among aceh cattle has different hair colors. These findings mean that drip loss was not influenced by meat types and hair color in cull female Aceh cattle. The drip loss values recorded in this study were in agreement with those reported by Harris and Karmas [26] that drip loss in beef ranges from $1 \%$ up to $30 \%$. Factors influence drip loss are meat cellular protein, temperature, rigor, membrane integrity, pre-slaughtering stress, processing and packaging (Troy dan Kerry 2010).

Water holding capacity can also represent by cooking loss, measurement of drip loss occurred by using heating. The higher fluid exudes from meat the lower the holding capacity of water has by the protein of meat. Cooking loss of silver side $(30.13 \pm 10.84 \%)$ and sirloin (32.06 \pm $7.30 \%$ ) was not significantly different and still belonged to the range of beef cooking loss, 15-40\% [20]. Cooking loss was influenced by the status of myofibril contraction. Shorter myofibril increase cooking loss, but the increases in age or fattening reduce cooking loss.

\section{Conclusion}

Sirloin and silver side meats of female aceh with different hair colors have relatively similar physical qualities that could be categorized into I-II or II-III grades. Meat physical quality of aceh cattle was not influenced by meat type or cattle hair colors.

\section{Acknowledgments}

This paper is supported by USAID through sustainable higher education research alliances (SHERA) Program Center for Collaborative for Research Animal Biotechnology and Coral Reef Fisheries (CCRANBIOCORE).

\section{References}

1 Pacheco PS, Restle J, Filho DC, et al.: Carcass physical composition and meat quality of Charolais cattle of different categories. R. Bras. Zootec. 2011; 40:2597-2605.

2 Moss J, Morley P, Baker D, et al.: eds. Improving Methods for Estimating Livestock Production and Productivity. Literature Review. University of New England, London. 2016.

3 Agus A, Widi TSM: Current situation and future prospects for beef cattle production in Indonesia-A review. Asian-Australas J Anim Sci. 2018; 31:976-983.

4 Rosiana N, Feryanto: Evaluation of self sufficiency of beef cattle in Indonesia. In PERHEPI ed.)^eds.). pp. 209-227, Jakarta. 2014.

5 Vaz FN, Pascoal LL, Pacheco PS, et al.: Fatness Beef Cattle Purchase Transactions Study in a Abattoir Firm in the Rio Grande Do Sul State. American International Journal of Contemporary Research. 2014; 4:165-174.

6 Mirza I, Rahayu W: Model pengembangan kawasan peternakan sapi aceh di Kabupaten Aceh Jaya Propinsi Aceh. Jurnal Peternakan Indonesia. 2017; 19:9. 
7 Nahaba B: Daging “Meugang” di Aceh Capai Harga Tertinggi di Indonesia ed.)^eds.) 2014.

8 Yunus M: Pidie paling tinggi konsumsi daging. In Serambi Indonesia ed.)^eds.), Banda Aceh. 2014.

9 Martojo H: Indigenous bali cattle: The best suited cattle breed for sustainable small farms in Indonesia. ed.)^eds.), Faculty of Animal Science, Bogor Agricultural University, Bogor, Indonesia. 2003.

10 Noor RR: Genetika Ternak. Penebar Swadaya, Jakarta. 2008.

11 Santosa U: Tata Laksana Pemeliharaan Ternak Sapi. Penebar Swadaya, Jakarta. 2005.

12 Tizioto PC, Gromboni CF, Nogueira AR, et al.: Calcium and potassium content in beef: Influences on tenderness and associations with molecular markers in Nellore cattle. Meat Science. 2014; 96:436-440.

13 Crouse DJ, Cundiff VL, Koch MR: Comparisons of Bos indicus and Bos taurus inheritance for carcass beef characteristics and meat palatability. J. Anim. Sci. 1989; 67:2661-2668.

14 Lage FJ, Paulino PV, Filho SC, et al: Influence of genetic type and level of concentrate in the finishing diet on carcass and meat quality traits in beef heifers. Meat Sci. 2012; 90(3):770-774.

15 Azhar A, Lubis TM, Razali: Nutrient composition and diversity of genes influence tenderness and cooking smells of the meat of local aceh cattle. ed.)^eds.). p. 74, Universitas Syiah Kuala, Banda Aceh. 2016.

16 Ministry of Agriculture tRoI: No. 54/permentan/ot.140/10/2006.

17 (SNI) INS: Quality of carcass and meat of cattle. (Agency, N. S., ed.)^eds.), Jakarta. 2008.
18 Sriyanni PLN, Tirta NIA, Lindawati AS, et al:: Physical quality of goat meat In a traditional slaughtering house at Denpasar. Majalah Ilmiah Peternakan. 2015; 18:48-51.

19 Lukman WD, Sudarwanto S, Sanjaya WA, et al.: Manual for Practical Work of the Hygiene of Anima Originated Food. ed.)^eds.), Bogor Agricultural University., Bogor. 2012.

20 Lawrie RA: Meat science. CRC Press, London, UK. 1998.

21 Jugde MD, Forrest JC, Hendrick HB, et al: Principle of Meat Science. Kendall Hunt Publishing Co., Dubuque, Iowa. 1989.

22 Onyango CA, Izumimoto M, Kutima PM: Comparison of some physical and chemical properties of selected game beefs. Beef Sci. 1998; 49:117-125.

23 Boles JA, Shand PJ: Effect of muscle location, fiber direction, and slice thickness on the processing characteristics and tenderness of beef stir-fry strips from the round and chuck. Meat Sci. 2008; 78:369 374.

24 Agustina KK, Cahya MRD, Widyantara GM, et al.: Nutrition level and physical quality of bali beef according to the sex and age of cattle. Bul. Vet. Udayana. 2017; 9:156-163.

25 Otto G, Roehe R, Looft $\mathrm{H}$, et al.: Comparison of different methods for determination of drip loss and their relationships to meat quality and carcass characteristics in pigs. Meat Sci. 2004; 68:401-409.

26 Harris SR, Karmas E: Evaluation of nutruent druing food processing. ITB., Bandung.1989. 